\title{
0 poder sacralizado dos clérigos de Castela (século XIII e início do século XIV)
}

\author{
The sacralized power of the clerics of Castile (13th and early 14th centuries)
}

\author{
Leandro Alves Teodoro* \\ Universidade Estadual de Campinas (Unicamp), Campinas, SP, Brasil \\ Universidade Estadual Paulista (UNESP), Franca, SP, Brasil
}

\begin{abstract}
RESUMO: A partir da primeira metade do século XIII, começaram a surgir obras escritas em castelhano destinadas a regular as funçôes atribuídas ao clero diocesano da Coroa de Castela. Serializando livros em verso, constituiçốes de sínodos e outros materiais voltados à formação basilar do clero que foram elaborados entre o século XIII e o XIV, o presente estudo visa examinar a promoção do poder da consagração da Eucaristia e o papel instrutivo da celebração da missa nesse momento de revigoramento da ação pastoral dos bispos ibéricos e de ampliação dos atributos das igrejas paroquianas. Em outras palavras, o alvo deste trabalho consiste em analisar as medidas adotadas por grandes autoridades eclesiásticas para a sacralização das falas e dos gestos articulados pelos clérigos ordenados nesse período.
\end{abstract}

PALAVRAS-CHAVE: Coroa de Castela. Sacramento da Eucaristia. Clero diocesano. Séculos XIII e XIV.

\begin{abstract}
From the first half of the thirteenth century, there was an emergence of works written in Castilian language destined to regulate the functions attributed to the diocesan clergy of the Crown of Castile. By serializing books in verse, synod constitutions and other texts focused on the basic formation of clerics, elaborated between the thirteenth and fourteenth centuries, this study aims to examine the promotion of the power of Eucharist consecration and the instructional role of the Mass celebration at a time when the pastoral action of Iberian bishops and the expansion of the attributes of the parish churches were strengthened. In other words, the aim of this work is to analyze the measures adopted by great ecclesiastical authorities regarding the sacralization of speeches and gestures of clerics ordained during that period.
\end{abstract}

KEYWORDS: Crown of Castile. Sacrament of the Eucharist. Diocesan clergy. 13th and 14th centuries.

\footnotetext{
* Professor permanente do Programa de Pós-Graduação em História da Universidade Estadual Paulista (UNESP/Franca) e bolsista Jovem Pesquisador da Fundação de Amparo à Pesquisa do Estado de São Paulo (FAPESP) junto ao departamento de História da Universidade Estadual de Campinas (Unicamp). Este artigo foi desenvolvido no âmbito do projeto “O ensino da fé cristã na Península Ibérica (sécs. XIV e XV)" (Processo Fapesp 2017/11111-9).

E-mail: leandroateodoro@uol.com.br https://orcid.org/0000-0002-5580-8838
} 
Na primeira metade do século XIII, o clérigo Gonzalo de Berceo - atuante no Mosteiro de San Millán de la Cogolla, localizado na região de La Rioja - tornou-se o primeiro poeta espanhol conhecido a compor obras em língua vernácula dedicadas a três temas específicos: a vida de santos; a mística-doutrinária; e os louvores à Virgem Maria (GERLI, 1997, p. 15). Ao redigir versos em que eram articuladas liçóes acerca dos dogmas do Cristianismo ${ }^{1}$, esse célebre autor dirigia as suas palavras especialmente aos simples clérigos, isto é, aos sacerdotes que não dominavam a celebração dos sacramentos e outras tarefas a eles atribuídas. ${ }^{2}$ Essa vontade de amparar a ação de clérigos castelhanos é evidente na obra Vida de santo Domingo de Silos, em que tal eclesiástico, logo no título de abertura, apregoa: "[...] de um confessor santo quero fazer uma prosa ${ }^{3} \mathrm{em}$ romance paladino, que o povo está acostumado a falar com seu vizinho". ${ }^{4}$ Por visar uma escrita em "romance paladino", isto é, em uma linguagem clara e inteligível a todos, esse clérigo construiu um enredo atrativo e passível de ser memorizado por clérigos de diferentes regióes e níveis de instrução.

Ainda que provavelmente uma grande parte das obras de Gonzalo de Berceo tivesse sua circulação reduzida ao Mosteiro de San Millán de la Cogolla, versos com esse conteúdo doutrinário alimentavam a esperança de tornar o clero castelhano-leonês conhecedor de ensinamentos correntes em outros reinos católicos acerca dos sacramentos da Igreja e da conduta cristã (FERNÁNDEZ CONDE, 2005, p. 471). Na primeira metade do século XIII, por mais que não tenha legado uma produção prescritiva ou tratados de cunho doutrinário, Gonzalo de Berceo foi um dos grandes promotores da ortodoxia romana ao fazer da poesia um terreno para a pregação (LACARRA; CACHO BLECUA, 2012, p. 359), dando especial destaque ao ensino de certas bases do Cristianismo por meio de versos que enriqueceram as referências em língua castelhana acerca da devoção e da piedade cristã (LAPPIN, 2002, p. 221). Como veremos ao longo deste artigo, Berceo lançou um debate acerca não só do rito romano ou do valor salutar da hóstia, mas também da figura humana de Cristo que foi se atualizando especialmente em sínodos organizados por prelados imbuídos da tarefa de educar o clero diocesano e instituir a celebração dos sete sacramentos da Igreja conforme os grandes pensadores cristãos propunham, tais como o jurista bolonhês Graciano e o escolástico São Tomás de Aquino. ${ }^{5}$ Dito de outro modo, os autores mencionados neste estudo deram os primeiros passos para a correção dos simples clérigos e a instituição do sacramento da Eucaristia na Coroa de Castela.

Nessa mesma Vida de santo Domingo de Silos mencionada acima, Gonzalo de Berceo compromete-se a estabelecer parâmetros de ação para os confessores de seu tempo, sobretudo os menos instruídos, ao enaltecer o comportamento de seu retratado Domingos de Silos, personagem emblemático do século onze. Em certa altura da obra, o poeta lança este comentário acerca do ofício pastoral:

Nosso Senhor Dom Cristo, tão alta podestade,

Disse que pastor era, e bom de verdade:

Bispos e abades; quantos têm dignidade,

Pastores são chamados sobre a cristandade.

Senhor Santo Domingo primeiro foi pastor,

Depois foi das almas padre, e guardador.

Bom foi no começo; no final, melhor,

O Rei dos céus nos dê o Seu amor. ${ }^{6}$ 
Lançando mão de versos como estes, conhecidos por seguir o estilo poético da cuaderna vía, que se estruturava a partir de quatro versos de catorze sílabas com rimas consoantes (TIMMOS; BOENING, 2016, p. 6), ${ }^{7}$ Gonzalo de Berceo, além de introduzir elementos para uma pregação de caráter mais dinâmico e repleta de exemplos da atuação cotidiana do clero, discorreu acerca do potencial salutar do ofício pastoral. Depois desses versos, ele ainda acrescentou que Domingos de Silos orava pelos enfermos e pela alma dos fiéis mortos, celebrava missas, zelava pelas igrejas e cuidava de seu corpo, praticando jejuns e mesurando a fala. Reconhecido como uma luz do Cristianismo para toda a abadia, o Domingos de Silos pintado por Gonzalo de Berceo reforçava o mérito de se dedicar a uma vida em prol não apenas da salvação da própria alma, mas também daquelas por ele assistidas. Nesses tempos de descobertas de novos caminhos para a manutenção da liturgia católica, essa vida de santo de Gonzalo de Berceo - bem como outras de suas produções, sobretudo o livro Del sacrificio de la misa, sobre o qual falaremos adiante -, convida-nos a penetrar no terreno do revigoramento do poder eclesiástico na Coroa de Castela.

Serializando as obras eclesiásticas que melhor definiram em vernáculo o rito eucarístico - como os versos do clérigo Gonzalo de Berceo, um sermão do franciscano Juan de Zamora e especialmente constituições sinodais sentenciadas no início do século XIV -, o presente artigo visará contar uma história do fortalecimento do poder atribuído aos sacerdotes de consagração da hóstia. Essa história acerca dos ritos litúrgicos abre uma fresta que permite espreitar não apenas o universo da manutenção da Igreja católica, do combate aos resquícios moçárabes ou de inter-relação entre poder temporal e poder espiritual, mas também o mundo de um ordenamento moral específico, o do ensino dos valores por meio de gestos e palavras de consagração - um mundo que será explorado nos limites deste trabalho.

\section{O poder da consagração}

Nesse período de efetivação do rito litúrgico romano em terras castelhanas, o livro Del sacrificio de la misa, de Gonzalo de Berceo, é a primeira obra poética em língua castelhana conhecida a tratar da consagração do corpo e do sangue de Cristo. A obra é constituída por estes quatro eixos: os templos dos antigos sacrifícios e a instituição do Cristianismo (da estrofe 1 à 31); a missa dos catecúmenos (da estrofe 32 à 54); a missa dos fiéis católicos com ênfase sobre a homilia, o rito da comunhão e a profissão da fé (da estrofe 55 à 247); e, por fim, o rito pós-comunhão (248 à 297) (ESCUER-RIERA, 2002, p. 39-40). Para discorrer acerca da consagração da hóstia, as palavras "sacrifício" e "oferenda" tornaram-se centrais nesses versos e ajudaram Berceo a definir o poder salutar da missa, bem como o sentido conferido à Paixão de Cristo pela doutrina católica. Esse quadro de definições e usos alegóricos desses termos-chave ganharam seus contornos em estrofes como estas:

[Estrofe 56]

Isto é sine dubio coisa bem ordenada,

Ouvir primeiramente a lição consagrada,

Mostrá-la por suas palavras que é fé acabada;

Desejar cumprir a obra, oferecer a obrada. 
[Estrofe 57]

Quando se espalhou a lei nos primeiros tempos, Quando sacrificavam; não ofereciam dinheiro,

Mas ou [um] touro ou aves ou bode ou carneiro,

Porém tudo terminou com um Cordeiro.

[Estrofe 58]

Cristo foi o cordeiro, filho de tal Cordeira [Maria],

Que nem depois nem antes não teve companheira;

Assim se encerrou a primeira das leis,

E ordenou a nova firme e verdadeira. ${ }^{8}$

Nessa altura da obra, Gonzalo de Berceo começa a debater mais diretamente acerca da liturgia que desejava enraizar em Castela, deixando claras as diferenças entre a Lei Velha e a Lei Nova e demarcando as mudanças ocorridas nos sacríficos de adoração depois da crucificação de Cristo. Ao confrontar esses dois livros bíblicos, esse eclesiástico não buscou invalidar ou condenar a lei anterior a Cristo, mas, sim, concebê-la como o prenúncio de um acontecimento maior; ou melhor, como antecedentes de ritos mais completos e condizentes com o novo momento anunciado pela morte do Filho de Deus (ESCUER-RIERA, 2002, p. 50). Nesse sentido, esses versos ensinavam que os ritos da Lei Velha eram um estágio ainda imperfeito ou inacabado do que viria a ser a liturgia cristã inspirada pelo Evangelho. Aos olhos de Gonzalo de Berceo, a história era evolutiva e, como tal, permitia aos homens mapear o encadeamento dos fatos e descobrir a relação estabelecida por Deus entre eles. ${ }^{9}$

A estrofe 22 resume magistralmente essa crença que move Gonzalo de Berceo a justificar a ligação entre as duas leis, a Velha e a Nova, ao proferir estas palavras: "Todos os sacrifícios, os da lei primeira/ todos significavam a Hóstia verdadeira;/ esta foi Jesus Cristo, que abriu o caminho, pela qual podemos regressar à morada primeira" ${ }^{10}$ Mergulhado numa corrente teológica que remonta a Orígines, ${ }^{11}$ o Del sacrificio de la misa identifica a Lei Velha como uma prefiguração da vida de Cristo, deixando evidente o valor profético e tipológico desse conjunto de textos bíblicos. Essa perspectiva teológica em que um fato histórico do Antigo Testamento é retomado para ajudar na interpretação do Novo Testamento é bastante evidente nestes versos que antecedem a referida estrofe 22: "Todas estas oferendas, as aves e gados, trazem significados de obscuros pedidos; todos em Jesus Cristo foram acabados, que ofereceu sua carne por nossos pecados". ${ }^{12}$ A palavra "significados" empregada no trecho serve para rememorar a relação de analogia entre o Antigo e o Novo Testamento e esclarecer que certos sacrifícios dos tempos anteriores a Cristo poderiam ser uma prefiguração de Sua paixão e morte na cruz. Dito de outro modo, essa palavra também é utilizada como sinônimo de "signo" e "figura" da hóstia consagrada na missa, já que os antigos sacrifícios ilustravam, segundo Berceo, uma lição ulterior e obscura, da qual se poderia extrair sinais proféticos da própria consagração do corpo do Filho de Deus. ${ }^{13}$

Lançando luz sobre essa malha de relações entre a Velha e Nova Lei, declama Gonzalo de Berceo: "O bode que matava a gente sacerdotal/ para Ele significava a Sua carne mortal" (estrofe 19). ${ }^{14}$ Neste início de estrofe, utilizava não o substantivo "significado", mas o verbo “significar”, deixando mais clara a relação por ele proposta entre os dois textos bíblicos, ao afirmar categoricamente que o 
cordeiro simbolizava a carne de Cristo, por prefigurar o maior sacrifício da história do Cristianismo. A tipologia sacrifício-Cristo está evidenciada neste e em outros versos em que o cordeiro Pascal do Antigo Testamento (Ex. 12, 1-11) representava a inauguração de uma nova etapa na vida dos homens, a da construção de uma Igreja erguida em memória da ressurreição do Filho de Deus (DEYERMOND, 1978, p. 99). Do mesmo modo como o sacrifício inacabado de Isaac era uma figura da própria morte de Jesus, esse martírio na cruz deveria ser eternamente rememorado pelos católicos por meio da celebração no altar da vida e morte do Filho de Deus, de modo que Ele fosse visto como fonte de inspiração para a piedade cristã. Essa relação entre passado e presente foi construída na obra do poeta de La Rioja a partir de estrofes como a 162, em que Gonzalo de Berceo diz: "No pão e vinho, aí fica o sabor,/ mas não é pão nem vinho, é coisa muito melhor:/ corpo é de Dom Cristo, o nosso Salvador;/ que isto não se cresse, seria um grande erro". ${ }^{15} \mathrm{Num}$ período em que a obrigatoriedade da comunhão anual começava a ganhar respaldo e a se instaurar especialmente pela intermediação de legados papais, esse verso e outros do livro Del sacrificio de la misa, em que a mesma temática é explorada, colaboraram para a introdução no vocabulário castelhano dos significados conferidos pela cúpula da Igreja de Roma ao pão eucarístico.

Embora a palavra "transubstanciação" 16 não apareça nos versos de Gonzalo de Berceo, como aparecerá na produção diocesana do século XIV, esse poeta de San Millán de la Cogolla não deixou de discorrer acerca da transformação do pão e do vinho em corpo e sangue de Cristo e de contribuir para a sacralização do ofício dos clérigos, conferindo-lhes um lugar privilegiado na intermediação entre o plano divino e o humano. O uso simbólico do par Cristo-missa, sacrifício e adoração, serviu para fundamentar as práticas dos clérigos ordenados e legitimar a cerimônia de elevação do cálice (PALAZZO, 2000, p. 27), já que o objetivo de tal autor e de outros letrados da Igreja era fazer desses membros do clero os únicos autorizados a consagrar o pão eucarístico durante a missa. Vale recordar que a doutrina da transubstanciação, oficializada pelo IV Concílio de Latrão (1215), ${ }^{17}$ demorou para ser ensinada em diferentes dioceses, especialmente na Península Ibérica, em que canonistas - como o bispo Pedro de Cuéllar, autor de um livro sinodal promulgado no ano de 1325 , sobre o qual voltaremos a falar depois - precisaram elaborar tratados em vernáculo para que prédicas acerca de tal temática se disseminassem por diferentes regiões desse território.

No que toca ao poder de consagração, Gonzalo de Berceo justifica o desempenho do clérigo ordenado ao afirmar:

\section{[Estrofe 275]}

Depois o santo clérigo, o que a missa canta,

Dando grandes suspiros, toma a hóstia santa,

Que a parta duas vezes logo que a levanta,

Faça três pedaços a partir do que parte.

[Estrofe 276]

O pedaço que tem na mão direita,

Com que benze o cálice assim esse misacantano, ${ }^{18}$

Isso faz pelos vivos, pelo povo cristão,

Que livre Deus as almas do furioso milhafre. ${ }^{19}$ 


\section{[Estrofe 277]}

Dos dois que li ficam, o primeiro faz memória

Das almas purgadas que estão com Deus na Glória,

O terceiro pedaço, como diz a história ${ }^{20}$

Roga pelos que padecem na lei purgatória. ${ }^{21}$

Tal cena da elevação da hóstia descrita por Gonzalo de Berceo tornou-se um dos pilares da liturgia cristã promovida nesses tempos e foi determinante para a emersão de novas práticas devocionais no seio da sociedade católica, como a comunicação direta com Cristo a partir do recebimento de Seu corpo. ${ }^{22}$ Esse modelo de celebração, na mesma medida em que restringiu aos clérigos a consagração da hóstia e o poder de elevação do cálice, fazendo dos leigos os espectadores de um complexo cerimonial acompanhado de atos de adoração e louvor, servia para despertar uma comoção geral por meio de mensagens absorvidas pelos sentidos da vista e do ouvido. A ação de ver a hóstia levantada, seguida pela de ouvir as badaladas dos sinos da igreja, criava um ambiente de recolhimento e reflexão, de modo que os olhos e ouvidos desses homens e mulheres se transformaram em canais de sensibilização da alma e de abrandamento do corpo (NAGY; BOQUET, 2015, p. 261).

No século XIII, época em que a Coroa de Castela vivia um período de aprendizagem dessas práticas devocionais e de incentivo à escrita acerca das experiências cristãs de vivência nesse ambiente de louvor, o franciscano Juan Gil de Zamora ${ }^{23}$ contribuiu com seu quinhão para que se mantivesse acesa a fé na celebração da Paixão de Cristo. Algumas décadas depois de Gonzalo de Berceo elaborar a obra Del sacrificio de la misa, esse religioso elaborou seu Liber sermonum, um conjunto de setenta sermões em que abordou diferentes matérias, tais como a vida, a morte e a ressurreição do Filho de Deus; a Virgem Gloriosa; os mártires da Igreja; os clérigos novatos; e muitas outras. É na primeira parte do sermonário que esse religioso retoma mais diretamente um assunto bastante caro à obra de Gonzalo de Berceo: a humanização de Cristo e os benefícios da celebração de Seu sacrifício. Em um sermão acerca do domingo de Ramos - cujo tema é este trecho do Cântico dos Cânticos: "Brotaram as flores em nossa terra, chegou o tempo da poda" (Ct 2, 12) $)^{24}$-, Juan Gil de Zamora explica que, como certos galhos de uma árvore precisariam ser cortados para que ela ganhasse a sua forma ideal, a vida de um fiel católico tinha de sofrer constantes intervençôes para se moldar à imagem de Cristo.

Visando deixar mais claro e evidente o mote de sua prédica, tal mendicante abre seu sermão com este argumento: "E baixo a metáfora das flores nos trazem à memória o sacramento da Paixão do Senhor quando se dize primeiro: 'Brotaram as flores..., etc.' Quanto mais se aproxima a Paixão de Cristo, tanto maior deve ser a devoção de seus fiéis e a purificação das almas.” Na sequência, o franciscano continua a interpretar a referida passagem do texto bíblico Cântico dos Cânticos ao acrescentar: "Como já começa a aproximar-se a Paixão de Jesus Cristo, já começa a resplandecer, por isso o Espírito Santo, para que quem deseja preparar-se se esforça para recebê-la, diz: 'Brotaram as flores em nossa terra...”. Juan Gil de Zamora justifica que o Espírito Santo transmite duas liçóes por meio desse trecho do Cântico dos Cânticos. O primeiro ensinamento, contido no início do versículo, explica que o trecho bíblico as "flores brotadas em nossa terra" se refere ao "sacramento da Paixão do Senhor" ministrado diante dos olhos dos cristãos; isto é, diz respeito à celebração de Sua morte como manifestação de esperança e redenção. ${ }^{25}$ Já o segundo ensinamento, expresso na sequência 
da mesma passagem bíblica, consiste em alertar o fiel para que aprendesse a podar toda ambição e, assim, cultivar uma vida virtuosa. Nessa trama propalada em um sermão redigido em latim, a "flor" simboliza não apenas as qualidades de Cristo, mas também a vida humana em constante amadurecimento, pelo fato de ela demandar cuidados assim como uma árvore em crescimento. ${ }^{26}$

Em um texto voltado também para servir de parâmetro e fonte para outros sermóes, Juan Gil de Zamora constrói um raciocínio metafórico em torno da interpretação dos significados do vocábulo "flor" empregado no Cântico dos Cânticos. Se Gonzalo de Berceo cruza o Antigo e Novo testamentos para costurar uma teia de prefigurações e pós-figuraçóes do sacrifício de Cristo, esse franciscano confecciona um sermão em que o sentido alegórico das palavras desse texto sapiencial é visto como um chamado divino para os fiéis se comoverem com a pureza e a qualidade das ações vivenciadas pelo Filho de Deus na Terra. Acerca dos usos metafóricos da Sagrada Escritura, analisa Juan Gil de Zamora que, "nas flores, podemos considerar três coisas pelas quais podemos comparar a Paixão de Cristo” com elas, a saber: um vermelho vivo, uma brancura intensa e um cheiro agradabilíssimo. Como as flores, "no Filho de Deus pode encontra-se o vermelho da Paixão, a brancura de Sua inocência e o cheiro de todas Suas virtudes e graças”. ${ }^{27}$ No universo de metáforas e símbolos construídos por obras como esse sermão sobre o domingo de Ramos, o mundo vegetal era geralmente associado à pureza, ao contrário do mundo animal - formado por carne e ossos, que poderia representar o vício e a impuridade (PASTOUREAU, 2004, p. 95). A associação de Cristo à flor ajudaria a convencer os fiéis a sempre identificar o Seu corpo como um cordeiro puro e sem pecados, que foi sacrificado a fim de que os homens não perdessem a esperança e nunca se esquecessem de seguir a Sua doutrina.

No supramencionado sermão de Juan Gil de Zamora, a metáfora da flor visava constranger os fiéis a partir do estímulo de seus sentidos, especialmente do olfato e da vista. Esse recurso é mais evidente na altura em que esse franciscano afirma que "a cruz de Cristo é uma flor por causa do cheiro de seus bens, graças e virtudes" e que dela "não sai qualquer cheiro, pois, como o cheiro da vinha afugenta os sapos, assim o cheiro da cruz de Cristo afugenta os demônios". ${ }^{28}$ A passagem ganha ainda mais relevância ao se amparar neste fragmento do Eclesiásticos: "Eu frutifiquei como uma vinha a doçura de Meu cheiro e Minhas flores são fruto de honra e honestidade". ${ }^{29}$ Ao se enveredar pela própria realidade de homens e mulheres, explorando sensaçóes experimentadas por diferentes tipos de fiéis como a aspiração do aroma da vinha, esse franciscano fazia da associação entre a natureza e o poder salutar de Cristo um meio de persuasão. Nesse período, em que se ampliava a prática de uma devoção introspectiva e voltada para a correção da consciência do fiel pecador, os versos de Gonzalo de Berceo e esse sermão de Juan Gil de Zamora procuravam ensinar que, por trás da realidade física, da materialidade das coisas e mesmo das impressóes sensoriais, Deus havia depositado mensagens que tinham de ser desvendadas pelos humanos. ${ }^{30}$ Os versos já analisados do referido clérigo de La Rioja enfatizam a necessidade de cada fiel católico aprender a filtrar as suas sensações para saber como traduziria a lição divina oferecida durante a missa, sobretudo no momento em que os olhos assistiriam à consagração do corpo de Cristo.

O Liber sermonum, de Juan Gil de Zamora, e o Del sacrificio de la misa, de Gonzalo de Berceo, contribuíram para a inauguração na Coroa de Castela de uma fé ancorada no culto à figura humana e divina de Cristo. Essa última obra sugere que a consagração da hóstia facilitaria a conversão individual, pela qual o católico, tocado e contrito, aprenderia que a missa deveria ensinar não apenas por meio da prédica do padre, mas também das imagens e objetos presentes na igreja 
e do ritual litúrgico ali celebrado. ${ }^{31}$ Durante a consagração da hóstia no altar, a meta era atrair os olhos dos fiéis e convencê-los a realizar um pacto tácito com Deus em que se comprometeriam a estar unidos a Cristo, dividindo com Ele a dor de Seu calvário. ${ }^{32}$ Segundo Gonzalo de Berceo, era o sacerdote imbuído de um poder especial de mediar o humano com o divino que orquestrava esse plano devocional e proporcionava aos fiéis católicos a oportunidade de viverem a cena da Paixão.

$\mathrm{Na}$ Coroa de Castela, a prática da comunhão anual foi debatida em assembleias eclesiásticas que visavam atualizar a formação do clero a partir da leitura de recomendações acerca da maneira como deveriam celebrar os sacramentos, amparar os fiéis leigos, cuidar de suas condutas e zelar pelo estado de conservação dos bens eclesiásticos. Com a finalidade de explorar as dimensões do poder de consagração da hóstia, vejamos em que medida ensinamentos como esses oferecidos por Gonzalo de Berceo e Juan Gil de Zamora puderam se tornar familiares ao clero diocesano em boa parte da Península Ibérica.

\section{A reforma do culto eucarístico}

Nessa Castela em que o Mosteiro de San Millán de la Cogolla era um centro produtor de saber, a redefiniçãao do campo de atuação do poder eclesiástico veio ganhar força e consistência na segunda metade do século XIII (VARASCHIN, 1981, p. 266), especialmente durante o governo de Afonso X (1252-1284), que reservou significativo espaço em suas obras para dissertar sobre a formação de clérigos e religiosos. Essa investida do poder temporal no campo eclesiástico ocorreu especialmente a partir da confecção de obras de natureza jurídico-doutrinária, tal como o primeiro livro das Siete Partidas, destinado inteiramente ao debate de assuntos relacionados à fé católica e à atuação da Igreja, em que esse governante anuncia: "Dar a penitência não convém senão a homens [escolhidos] a quem se [de]vem os homens confessar; e isto se entende primeiramente por todos os prestes que são ordenados de missa, pelo nobre ofício que têm de consagrar o corpo de Nosso Senhor Jesus Cristo, e estão no lugar dos Apóstolos." ${ }^{33}$ Ao alegar que, ao rei de Castela e Leão, cabia o poder de legislar e de velar pela Igreja (RUCQUOI, 2012, p. 155), contrariando as esperanças universalistas da podestade romana, a produção de Afonso $\mathrm{X}$ não deixou de dissertar sobre esferas próprias da ação eclesiástica, isto é, de domínios em que nem o rei poderia agir: o da consagração da hóstia e o do exame da consciência na confissão. ${ }^{34}$ Melhor dizendo, a autonomia reivindicada por esse monarca era relativa ao governo dos bens da Igreja e das leis do foro externo, já que confiou aos bispos o governo das almas de seus súditos - bispos que, como veremos na segunda parte deste estudo, ecoaram boa parte dos ensinamentos elaborados pelo clérigo Gonzalo de Berceo na primeira metade do século XIII.

Embora as obras de Gonzalo de Berceo aqui mencionadas não sejam prescritivas como as Siete Partidas e tampouco tenham o mesmo volume de páginas desse compêndio jurídico-doutrinário, muitos de seus versos corroboraram com os argumentos de Afonso X e repercutiram fora da corte régia essa mesma opinião de que os sacerdotes-confessores representavam os Apóstolos na Terra e, por consequência, estavam imbuídos da tarefa de serem intermediários de Cristo. ${ }^{35}$ Nesse momento de repovoamento de diferentes regióes hispânicas e de expansão do poder catequético dos prelados diocesanos, ${ }^{36}$ os clérigos vieram a conhecer um conjunto de obras que corroborou para a promoção do ofício pastoral fora do âmbito da corte régia. Obras como as de Gonzalo de Berceo, além das constituiçôes de sínodos, mostram como o clero das dioceses da Coroa de Castela foi estimulado 
para celebrar as missas e oferecer a hóstia consagrada aos fiéis católicos que, paulatinamente, foram se dispersando por terras ocupadas por mouros durante séculos, ajudando a repovoá-la e a criar uma nova dinâmica social (LADERO QUESADA, 2014, p. 120-121).

Entre os séculos XIII e XIV, um dos sínodos que melhor definiu a celebração da Eucaristia, bem como de outros atributos do clero, foi o realizado pelo arcebispo de Toledo, o infante D. Juan de Aragão, no ano de 1323. Em uma constituição intitulada Da celebração de missas, tal prelado diocesano explicou aos clérigos como o sacramento da Eucaristia deveria ser ministrado, inclusive ensinando as palavras a serem empregadas durante o rito, ao afirmar: " $\mathrm{E}$, como que o sacramento do corpo e sangue de Cristo é o que com mais frequência se administra, devem com ele ser mais cautos os ministros, porque se pode errar com ele com mais perigo; convém, portanto, conbecer sua matéria e forma" ${ }^{37} \mathrm{Na}$ sequência, explica que "a matéria do sacramento do corpo de Cristo é um pão de trigo puro e ázimo e vinho de videira mesclado com pouca água, conservando a natureza do vinho". ${ }^{38}$ Fazendo de prédicas concernentes à natureza da celebração eucarística uma das pautas do dia de um sínodo, D. Juan de Aragão explicou ao clero que o Senhor quis tornar o pão e o vinho o próprio corpo e sangue de Cristo, transformando-os, desse modo, em alimento para a alma. Como os sacramentos possuíam uma matéria, sendo, em quase todos os casos, uma realidade concreta ${ }^{39}$, pela qual se acreditava que Deus se manifestaria, esse prelado diocesano enveredou por searas da escolástica ao ecoar a máxima de que o poder divino fazia da concretude das “coisas" - do pão, vinho, água e óleos - um suporte em que a graça agiria para se mostrar viva aos olhos dos fiéis. ${ }^{40}$

Distinguindo-se inclusive de muitos outros bispos por resumir cada elemento estruturante do sacramento da Eucaristia, logo depois de explicar a matéria desse rito, o prelado D. Juan de Aragão parte para outra esfera do signo sacramental, a sua forma. Na mesma constituição chamada Da celebração de missas, esse arcebispo afirma que "a forma que devemos seguir na consagração do corpo de Cristo é a seguinte: 'Este, é, pois, o cálice de Meu sangue, do novo e eterno Testamento, mistério de fé, que por vós e por muitos será derramado em remissão dos pecados'; depois de cujas palavras elevará o cálice com devoção e humildade". ${ }^{41}$ Seguindo uma opinião comum a vários canonistas e teólogos daquele período, esse arcebispo explica que o sacramento da Eucaristia possuía uma matéria, o pão e vinho, bem como frases performativas bastante precisas, a fim de que o sacerdote soubesse como santificar o altar a partir da consagração da hóstia. Os benefícios desse rito são oferecidos em uma operação mediada por palavras proferidas por Cristo e registradas no Novo Testamento (ROSIER-CATACH, 2004, p. 354), de modo que a fala articulada do sacerdote começava a ser central nesse jogo moralizante, cujas diretrizes eram estabelecidas por meio da celebração de assembleias, da escrita de sumas teológicas, manuais de confessores e de uma série de outras obras destinadas a regular as práticas litúrgicas dentro das igrejas católicas.

Se Gonzalo de Berceo deu um dos primeiros passos para o enraizamento da liturgia romana por meio de versos em língua vernácula, o prelado D. Juan de Aragão foi mais adiante nessa caminhada ao dissertar, assim como outras autoridades ibéricas do século XIV, acerca da própria constituição do sacramento da Eucaristia. A diferença entre esses dois eclesiásticos também diz respeito ao alcance maior das prédicas do segundo, já que seus ensinamentos foram promulgados em uma assembleia e, por isso, deveriam ser familiares a todos os sacerdotes toledanos de cidades e campos. ${ }^{42}$ Além disso, enquanto o Del sacrificio de la misa, de Gonzalo de Berceo, e mesmo o Liber sermonum, de Juan Gil de Zamora, deslizam por uma mística doutrinária recheada de alegorias e lições diluídas em exemplos retirados da Sagrada Escritura, D. Juan de Aragão foca 
em leis e estatutos da Igreja em um texto prescritivo. A maneira como esse arcebispo aborda os sacramentos é própria de manuais de confessores e constituições sinodais - obras comprometidas a serem de fácil compreensão e a trazer ensinamentos sintéticos a respeito do ofício clerical. ${ }^{43} \mathrm{As}$ discussões a respeito da celebração eucarística e da pós-figuração de Cristo entram em Castela pelo intermédio da mística cristã e vão se firmando e ganhando terreno nas paróquias por meio de obras de canonistas e autoridades interessadas em estabelecer critérios para as ações dos sacerdotes da Península Ibérica.

Durante o século XIII, a produção do clérigo diocesano Gonzalo de Berceo ou mesmo do franciscano Juan Gil de Zamora abriram as portas de Castela para um movimento de valorização da vida de Cristo, sobretudo de suas ações, que poderiam ser retomadas e partilhadas pelos católicos de diferentes períodos e espaços. Na primeira metade do século seguinte, a partir de esforços de autoridades eclesiásticas, como o supracitado infante D. Juan de Aragão e de legados papais, a produção diocesana dessas terras atualiza-se com a finalidade de preparar melhor os párocos, ensinando-lhes a ministrar os sacramentos da Igreja da mesma forma como eram celebrados em outras plagas católicas do período em questão. Mesmo que a Primeira Partida, de Afonso X, tenha tocado nessa temática, esse livro não circulava entre as mãos de confessores desse período e apenas foi promulgado no ano de 1348 pelo rei Afonso XI. No que toca à missa, Afonso X - acompanhado de um corpo de juristas da coroa - já havia dissertado acerca do sacramento da Eucaristia, legando prédicas como esta: "Consagrar não deve nenhum clérigo o corpo de nosso Senhor Jesus Cristo quando disser a missa, a menos que haja estas três coisas: pão, vinho e água. [...] E esse pão muda-se verdadeiramente no corpo de nosso Senhor Jesus Cristo, e o vinho e a água, em Seu sangue [...]”. Na mesma lei em que inseriu tal enxerto, o referido monarca complementou seu raciocínio ao asseverar: "[...] E pelas santas palavras que diz o clérigo, que disse nosso Senhor Jesus Cristo no dia de quinta-feira da ceia [...] e disse aos apóstolos: 'Esse é Meu corpo e Meu sangue'”. ${ }^{4}$

Embora as semelhanças entre as prédicas do monarca Afonso X e de D. Juan de Aragão possam sugerir um padrão partilhado por obras monárquicas do início da segunda metade do século XIII e também pela produção diocesana do XIV, não se pode negligenciar uma diferença importante entre esses dois períodos: o poder maior de disseminação conquistado por obras de um arcebispo como esse infante de Aragão. As constituições de prelados diocesanos possuíam uma divulgação mais ampla no seio da sociedade eclesiástica castelhano-leonesa, pois todo clérigo beneficiado deveria possuir uma cópia em pergaminho desse tipo de documento em suas igrejas para se manter informado sobre a maneira como deveria gerir os bens eclesiásticos e cuidar de suas vidas e das almas dos fiéis. Ainda na primeira metade do século XIV - período em que D. Juan de Aragão e o legado papal Guillermo de Godin não mediram esforços para aplicar em Castela as diretrizes do IV Concílio de Latrão - a escrita desse gênero foi se expandindo em diferentes dioceses da Coroa de Castela e ganhando novos formatos e eixos moralizantes.

Em 1325, dois anos depois da celebração do sínodo de Toledo por D. Juan de Aragão, o bispo de Segóvia, D. Pedro de Cuéllar, organiza um sínodo em que apresenta ao clero local um livro moralizante repleto de sínteses concernentes aos preceitos elementares da fé católica, tais como os mandamentos da lei de Deus, os artigos da fé, os sacramentos da Igreja e uma série de outros rudimentos. Foi nesse livro que essa autoridade incluiu este ensinamento sobre o sacramento da Eucaristia: 
E apesar de os batizados serem guarnecidos do sacramento da Confirmação, porém, como tantas são as tentações do diabo contra ele, que cada dia que passa, [sentem-se] maus pelos pecados. Por isso, para estarem mais fortes e mais rézios ${ }^{45}$ na graça de Deus, necessário foi ter de comer espiritual, que é corpus Christi e o sangue verdadeiro e muito apreciado Dele. Por essa razão, ${ }^{46}$ diz Ele 'eu sou pão verdadeiro que do Céu desci, se alguém comer deste pão, viverá para sempre' e, diz Ele, 'a Minha carne verdadeiramente é comer e o Meu sangue verdadeiramente é beber' e por este comer são criadas e nutridas as almas dos justos. ${ }^{47}$

Repercutindo lições acerca do sacrifício de Cristo que tinham sido elaboradas pela primeira vez em castelhano por Gonzalo de Berceo e fomentando uma alegoria da Paixão cara ao já mencionado franciscano Juan Gil de Zamora, Pedro de Cuéllar removeu o último obstáculo que impedia os simples clérigos de Castela de poderem aprender sobre o significado do sacramento da Eucaristia. ${ }^{48}$ Escrito em vernáculo, e não em latim como as referidas constituições de D. Juan de Aragão, o livro sinodal desse bispo de Segóvia foi além nesse movimento de manutenção dos ritos romanos ao cruzar doutrinas da mística cristã com prescriçóes específicas a respeito da regulação do rito litúrgico que se espalhavam pelos reinos católicos pelo intermédio de manuais de confessores. ${ }^{49}$ Nesse trecho citado acima de seu livro sinodal, ao dissertar sobre uma analogia entre as necessidades alimentares do corpo e da alma, Pedro de Cuéllar explica que Deus fez da carne e sangue de Seu Filho o alimento que faltava para a alma do fiel católico se nutrir e se manter forte contra as tentações do diabo. Ao contrário de D. Juan de Aragão, que se limitou a justificar a matéria e a forma do sacramento da Eucaristia, esse bispo de Segóvia invadiu o território das alegorias bíblicas e abordou o uso cristão dos verbos "comer" e "beber" como açôes salutares de correção do espírito e de absorção da graça divina. É por isso que ele remata o capítulo com estas palavras: "Assim como pelo comer do fruto vedado foi perdido o homem, assim pelo comer do fruto de vida [ele] seja reparado". ${ }^{50}$

Pedro de Cuéllar discorre acerca do sacramento da Eucaristia em alguns capítulos de seu livro sinodal, destacando o significado desse rito, o tipo de pão e vinho utilizados para sua celebração, as medidas a serem tomadas contra o roubo da hóstia, as maravilhas proporcionadas pela comunhão e os cuidados recomendados aos clérigos para respeitarem o sacrifício de Cristo no altar. Em um desses capítulos, esse prelado aponta três "coisas" que resumem desde os elementos constituintes do sacramento da Eucaristia até os efeitos provocados pelo poder de consagração atribuído ao clérigo ordenado:

E deve saber o clérigo que, no sacramento do altar, existem três coisas. A primeira coisa é aquela que parece forma de pão e de vinho. A segunda é o corpo de Jesus Cristo. A terceira, a virtude do sacramento, que é unidade e caridade, que existe entre Jesus Cristo e os católicos. [...] A primeira coisa significa as duas postumeiras: o corpo e o sangue, a unidade; e a segunda, que é corpus Christi, significa a unidade dita que existe entre os católicos e Jesus Cristo. ${ }^{51}$

Nessa prédica do livro sinodal de 1325, Pedro de Cuéllar ressalta que o revigoramento do sacramento da Eucaristia, bem como do próprio do poder de consagração, criou uma atmosfera na missa propícia para que os fiéis católicos vivenciassem a caridade divina como elo entre eles e Cristo. Esse argumento já havia sido anunciado por Gonzalo de Berceo nesta altura em que ele descreve, no Del sacrificio de la misa, o significado dos animais sacrificados no Antigo Testamento: "A pomba significa a Sua simplicidade; a rolinha é signo de Sua castidade; os pães figuram que Ele 
era verdade, caminho, paz e vida em pão de caridade" (Verso 21). ${ }^{52}$ Nessas passagens e em outras em que também são abordados os benefícios da consagração da hóstia, Pedro de Cuéllar e Gonzalo de Berceo enfatizaram que o sacramento da Eucaristia rememorava o amor de Deus e estimulava a união entre os fiéis e a Igreja celeste, ajudando homens e mulheres a estabelecer um acordo tácito com Cristo em que se comprometiam a seguir os Seus passos na Terra.

Num período de fortalecimento do poder das dioceses ibéricas, o livro sinodal de Pedro de Cuéllar ajudou a enraizar no interior da Coroa de Castela, ainda que apenas da diocese de Segóvia, referências relativas à caridade e à própria Paixão de Cristo que vinham sendo alimentadas nessas terras desde a primeira metade do século XIII por obras como o Del sacrificio de la misa, de Gonzalo de Berceo. Divulgando esse material durante a celebração de um sínodo, tal bispo permitiu ao baixo clero e, consequentemente, aos fiéis de suas paróquias que se familiarizassem com um jogo vocabular específico do universo da celebração eucarística. Ao definir o uso de palavras, como o verbo "transubstanciar", que não apareciam nem mesmos nos versos do poeta de La Rioja (BIOGGINI, 2010, p. 109), o referido bispo colaborou para o enriquecimento da língua castelhana falada nas ruas, nas portas das igrejas e no convívio com os sacerdotes instruídos pelas diretrizes dos sínodos e concílios do século XIV. Nesse sentido, comparando o Del sacrificio de la misa com o livro sinodal de Pedro de Cuéllar, uma das primeiras conclusóes a que se chega neste estudo é referente ao potencial dos sínodos de admoestar os clérigos simples e ensiná-los, entre outras matérias, a gerir o poder a eles atribuído de celebrar o corpo de Cristo.

Os arcebispos e bispos da primeira metade do século XIV atualizaram as recomendações que haviam sido prescritas no IV Concílio de Latrão (1215) e criaram estratégias para colocar paróquias e catedrais em sintonia; mais precisamente, buscaram guiar as ações dos clérigos ordenados a fim de convencê-los a adotar os ritos romanos, a saber como instruiriam os fiéis leigos e fariam da consagração da hóstia um momento de profunda reflexão acerca do amor e da caridade de Deus. Juntamente com a promoção do sacramento da Eucaristia, foi-se fixando a crença na sacralização dos gestos e palavras dos sacerdotes, bem como a fé na possibilidade de se reviver o sacrifício de Cristo no altar de uma igreja.

Da escrita do Del sacrificio de la misa à celebração de um sínodo por Pedro de Cuéllar no ano de 1325 - como se pôde observar neste estudo -, o clero da Coroa de Castela assistiu a um movimento de fortalecimento do poder de consagração dos clérigos diocesanos. Vistos como pósfigura de Cristo, os sacerdotes tornaram-se personagens fundamentais para intermediar o humano com o divino, possibilitando aos fiéis a contemplação do pão eucarístico, enquanto esse objeto sagrado era elevado, santificado e entregue no altar como oferenda divina. Nesse contexto, o próprio corpo do padre é identificado como fonte de ensinamentos, já que seus braços estendidos e as palavras por ele pronunciadas contribuíam para alimentar a devoção dos católicos e convencê-los a acreditar na caridade divina.

A obrigação colocada ao fiel católico de se confessar e comungar todos os anos demandou esforços contínuos da cúpula letrada de arquidioceses e dioceses de diferentes partes do mundo cristão a fim de preparar melhor esses eclesiásticos para serem seus representantes nas paróquias e, consequentemente, guias do público que assistia às missas. Entre os séculos XIII e XIV, a história da devoção da Coroa de Castela ganhou novos contornos a partir do fortalecimento de um poder que cabia apenas aos clérigos ordenados gerir, o da consagração. A partir de obras escritas pelos próprios clérigos, em verso e prosa, a língua falada pelos mais simples enriqueceu e pôde partilhar 
novos vocábulos que ajudaram a conferir sentido ao universo da liturgia católica num espaço banhado por séculos pelas práticas moçárabes. Conforme os ritos romanos promovidos pelo IV Concílio de Latrão (1215) conquistavam as igrejas de Castela, a língua castelhana ganhou novas projeções e tornou-se, como outras línguas vernáculas, forte aliada de arcebispos e bispos para o revigoramento das ações pastorais.

\section{Referências}

ALFONSO X. Las siete partidas del rey Don Alfonso el sabio. Cotejadas con varios codices antiguos por la Real Academia de la Historia. t. I. Partida Primera. Madrid: En la Imprenta Real, 1807.

ALONSO, Martín. Diccionario Medieval Español, desde las glosas Emilianenses y Silenses (s. X) hasta el siglo XV. Salamanca: Universidad Pontificia de Salamanca, 1986.

ASTELL, Ann W. Eating Beauty: the Eucharist and the spiritual arts of the Middle Ages. Ithaca; London: Cornell University, 2006.

BÉRIOU, Nicole. Religion et Communication. Um autre regard sur la prédication au Moyen Àge. Genève: Droz, 2018.

BERNAL ESTÉVEZ, Angel. Poblamiento, transformación y organización social del espacio extremeño (siglos XIII al XV). Mérida (Badajoz): Editora Regional de Extremadura, 1998.

BIOGGINI, Olivier. Gonzalo de Berceo et l'actualisation de I'Histoire sacré. In: LUQUET, Gilles (ed.). La concordance des temps. Paris: Presses Sorbonne Nouvelle, 2017.

BIOGGINI, Olivier. Le temps des faits et le temps des mots: Gonzalo de Berceo et l'actualisation de l'histoire sacrée. In: LUQUET, Gilles (ed.). La concordance des temps. Moyen Âge et Époque moderne [en ligne]. Paris: Presses Sorbonne Nouvelle, 2010. p. 97-126. Disponível em: http://books.openedition.org/psn/2903. Acesso em: 15 ago. 2018.

CHELINI, Jean. Histoire religieuse de l'Occident Médiéval. Paris: Libraire Arthème Fayard/Pluriel, 2010.

DE CEVINS, Marie-Madeleine; MATZ, Jean-Michel. Structures et dynamiques religieuses dans les sociétés de l'Occident latin (1179-1449). Rennes: Presses universitaires de Rennes, 2010.

DEYERMOND, Alan. La estructura tipológica del sacrifício de la misa. Berceo, n. 94-95, p. 97-104, 1978.

DUTTON, Brian. Móviles de Berceo. In: RICO, Francisco (coord.). Historia y crítica de la literatura española. Edad Media. Coord. por Alan D. Deyermond. Barcelona: Editorial Crítica, 1979. v. 1. p. 148-151. Disponível em: http://vallenajerilla.com/berceo/dutton.htm. Acesso em: 22 ago. 2018.

ESCUER-RIERA, Iris. El Sacrificio de la Misa, de Gonzalo de Berceo. Estudio socio-cultural del poema con un análisis particular de su estrutura tipológica. Tese (Mestrado em Artes) - Department of French, Hispanic and Italian Studies, The University of British Columbia, Vancouver, 2002. Disponivel em: http://vallenajerilla.com/berceo/rieraescuer/sacrificiodelamisaberceo.htm. Acesso em: 5 jul. 2018.

FERNÁNDEZ CONDE, Francisco Javier. La religiosidad medieval em España. Plena Edad Media (Siglos XI-XIII). Oviedo: Ediciones Trea, 2005. (Colección Piedras Angulares).

GARCÍA Y GARCíA, Antonio (dir.). Synodicon Hispanum. Avila y Segovia. Madrid: Biblioteca de Autores Cristianos, 1993. v. VI.

GARCÍA Y GARCÍA, Antonio (dir.). Synodicon Hispanum. Cuenca y Toledo. Madrid: Biblioteca de Autores Cristianos, 2010. v. X.

GERLI, Michel. Introducción. In: BERCEO, Gonzalo de. Milagros de Nuestra Señhora. Edición Michael Gerli. Madrid: Cátedra, 1997.

GÓMEZ REDONDO, Fernándo. Historia de la prosa medieval castellana. La creación del discurso prosístico: el entramado cortesano. Madrid: Cátedra, 1998. v.1. 
BERCEO, Gonzalo de. Del sacrifício de la misa. Ed. y comentário Pedro M. Cátedra. In: Obra Completa. Edición y estúdios de vários autores coordenado por Isabel Uría. Madrid: Biblioteca Gonzalo de Berceo, 1992. Disponível em: http://vallenajerilla.com/berceo/catedra/sacrificiomisa.htm. Acesso em: 11 ago. 2018.

BERCEO, Gonzalo de. Escomienza la vida del glorioso confesor Sancto Domingo de Silos. In: Poetas castellanos anteriores al siglo XV. Colección hecha por Tomás Antonio Sánchez, continuada por Pedro José Pidal y aumentada e ilustrada por Florencio Janer. Madrid: M. Rivadeneyra, 1864. p. 39-64. (Biblioteca de Autores Españoles desde la formación del lenguaje hasta nuestros días, 58).

GUITTON, Jean. Le temps et l'eternité chez Plotin et Saint Augustin. Paris: Librairie philosophique J. Vrin, 1959. JACQUES, Paul. L'Église et la culture en Occident (IXe-XIle siècles). Paris: P.U.F., 1986. 2 v.

LACARRA, María Jesús; CACHO BLECUA, Juan Manuel. Historia de la literatura española: entre oralidad y escritura. La Edad Media. t. I. Barcelona: Crítica, 2012.

LADERO QUESADA, Miguel Ángel. La formación medieval de España. Madrid: Alianza Editorial, 2014.

LAPPIN, Anthony. The Medieval Cult of Saint Dominic of Silos. Leeds: Maney Publishing for the Modern Humanities Research Association, 2002.

LILLO REDONET, Fernando (ed.). Sermonario. Juan Gil de Zamora. Estudio preliminar, edición, traducción y comentario de siete de sus sermones. Zamora: Instituto de Estudios Zamoranos Florián de Ocampo, 2011.

LINEHAN, Peter. La iglesia Española y el papado en el siglo XIII. Salamanca: Universidad Pontificia de Salamanca, 1975.

LLORENTE RESINES, Luis. La catequesis em España. Historia y textos. Madrid: Biblioteca de Autores Cristianos, 1997.

LOPEZ GONZALEZ, Pedro. Res et sacramentum. Origen y aplicación al sacramento de la penitencia. Tese (Doutorado em Teologia) - Facultad de Teología, Universidad de Navarra, Pamplona, 1991.

LUIS MARTIN, José; LINAGE CONDE, Antonio. Religion y sociedad medieval. El catecismo de Pedro de Cuéllar (1325). Salamanca: Europa Artes Gráficas, 1987.

MACY, Gary. Theology of the eucarist in the high middle ages. In: LEVY, Ian Christopher; MACY, Gary; AUSDALL, Kristen Van. A companion to the Eucharist in the Middle Ages. Leiden; Boston: Brill, 2012.

NAGY, Piroska; BOQUET, Damien (dir.). Le sujet des émotions au Moyen Âge. Paris: Beauchesne, 2009.

NAGY, Piroska; BOQUET, Damien. Sensible Moyen Âge. Une histoire des émotions dans l'Occident médiéval. Paris: Éd. Le Seuil, 2015.

NIETO SORIA, José Manuel. El Pontificado Medieval. Madrid: Arco Libros, 1996.

PALAZZO, Éric. Liturgie et société au Moyen Age. Paris: Aubier, 2000.

PASTOUREAU, Michel. Une histoire symbolique du Moyen Âge occidental. Paris: Le Seuil, 2004.

RAMÓN LODARES, Juan. Las razones del castellano derecho. Cahiers d'Études Hispaniques Médiévales, n. 18-19, p. 313-334, 1993.

REAL ACADEMIA ESPAÑOLA. Diccionario de la lengua española. 22. ed. Madrid: Espasa, 2001. 2 v.

RITCHEY, Sara. Holy Matter: changing Perceptions of the Material World in Late Medieval Christianity. Ithaca; London: Cornell University Press, 2014.

RITCHEY, Sara. Spiritual Arborescence: trees in the medieval Christian imagination. Spiritus, n. 8, Johns Hopkins University Press, 2008.

ROSIER-CATACH. La parole efficace. Signe, rituel, sacré. Paris: Seuil, 2004.

ROSS, Ellen. 'She wept and cry right loud for sorrow and for pain': suffering, the spiritual journey, and women's experience in late medieval mysticism. In: WIETHAUS, Ulrike (ed.). Maps of flesh and light: the religious experience of medieval women mystics. Syracuse; New York: Syracuse University, 1993.

RUCQUOI, Adeline. Cuius Rex, Eius religio: Ley y religión en la España medieval. In: MAZíN, Oscar (ed.). Las representaciones del poder en las sociedades hispánicas. México, D. F.: El Colegio de México, Centro de Estudios Históricos, 2012. p. 133-174. 
RUCQUOI, Adeline. Los franciscanos en el Reino de Castilla. In: IGLESIA DUARTE, J. I. de la; GARCÍA TURZA, F. J.; GARCÍA DE CORTÁZAR, J. A. Actas. VI Semana de Estudios Medievales: Nájera, 31 de julio al 4 de agosto de 1995. Nájera: Instituto de Estudios Riojanos, 1996. p. 65-86.

SÁNCHEZ HERRERO, José. Alfabetización y catequesis en España y en América durante el siglo XVI. In: SARANYANA, J.-I. et al (ed.). Evangelización y teología en América (siglo XVI). X Simposio Internacional de Teología de la Universidad de Navarra. Pamplona: Servicio de Publicaciones de la Universidad de Navarra, 1990. v. 1. p. 237-263.

SMALLEY, Beryl. William of Auvergne, John of la Rochelle and St. Thomas Aquinas on the old law. In: SMALLEY, Beryl. Studies in medieval thought and learning: from Abelard to Wyclif. London: Hambledon Press, 1981.

SOTO RÁBANOS, José Maria. La ignorancia del Pueblo Cristiano llano, un obstáculo para el diálogo interrreligioso. In: SANTIAGO-OTERO, Horacio (ed.). Diálogo filosófico-religioso entre cristianismo, judaísmo e islamismo durante a Edad Media en la Península Ibérica: actes du Colloque international de San Lorenzo de El Escorial, 23-26 juin 1991. Organisé par la Société internationale. Turnhout: Brepols, 1994.

SOTO RÁBANOS, José Maria. Visión y tratamiento del pecado en los manuales de confesión de la baja edad media hispana. Hispania Sacra, v. 58, n. 118, p. 411-447, 2006.

TEJADA Y RAMIRO, Juan. Coleccion de canones y de todos los concilios de la Iglesia española y de America. t. III. Madrid: Imp. de Jose Maria Alonso, 1859.

TIMMOS, Patricia; BOENING, Robert. Gonzalo de Berceo and the Latin Miracles of the Virgin. A translation and a Study. New York: Routledge, 2016.

ULLMANN, Walter. Public welfare and social legislation in the early medieval councils. Studies in Church History, v. 7, p. 1-39, 1971.

VALDEÓN BARUQUE, Julio. Población y repoblación. In: MENENDEZ PIDAL, Ramon. La Baja Edad Media Peninsular, siglos XIII al XV: la población, la economia, la sociedade. Madrid: Espasa Calpe, 1996. (Tomo XII de Historia de España).

VARASCHIN, Alain. San Millan de la Cogolla: le temps du monastère ou l'imaginaire de Gonzalo de Berceo. Cahiers de Civilisation Médiévale, v. 24, n. 95-96, p. 257-267, 1981.

VOGEL, Cyrille. Une mutation cultuelle inexpliquée: le passage de l'Eucharistie communautaire à la messe privée. Revue des Sciences Religieuses, n. 54-53, p. 231-250, 1980.

WILLIS, Raymond S. 'Mester de clerecía'. El 'libro de Alexandre’ y la tradición de la cuaderna vía. In: RICO, Francisco (coord.). Historia y crítica de la literatura española. Edad Media. Coord. por Alan D. Deyermond. Barcelona: Editorial Crítica, 1979. v. 1. p. 141-144. Disponível em: http://vallenajerilla.com/berceo/willis.htm. Acesso em: 22 ago. 2018.

\section{Notas}

${ }^{1}$ Como afirmou o pesquisador Brian Dutton: “Su público es en esencia el de los juglares, y para publicar sus obras, tendría que recurrir a los 'habituales propagadores de toda literatura', y estos juglares devotos recitarían sus obras em las romerías de los santuarios" (DUTTON, 1979).

${ }^{2}$ A respeito da formação do clero diocesano de Castela, ver: SÁNCHEZ HERRERO, 1990; SOTO RÁBANOS, 1994.

${ }^{3}$ A palavra “prosa" é empregada como sinônima de "composição métrica" (ALONSO, 1986, t. II, CH-Z, p. 1526).

4 “En el nomne del Padre, que fizo toda cosa,/ Et de don Jhesu Chisto, fijo de la Gloriosa,/ Et del Spiritu Sancto, que egual dellos posa,/ de um confessor santo quiero fer una prosa. Quiero fer uma prosa en roman paladino, en qual suele el pueblo fablar a su veçino" (BERCEO, 1864, p. 39).

${ }^{5}$ Acerca dos grandes debates teológicos que reformaram os cultos católicos, consultar: CHELINI, 2010, p. 383-410; JACQUES, 1986, p. 593-645.

6 “Nuestro sennor don Christo, tan alta podestat/ Dixo que pastor era, e bueno de verdat:/ Obispos, e abades, quantos an dignidat,/ Pastores son chamados sobre la christandat/ Sennor Sancto Domingo de prima fué pastor,/ Depues fué de las almas padre, e guardador/ Bueno fué en comienzo, a postresmas meior/ El Rey de los çielos nos dé el su amor" (BERCEO, 1864, p. 40). 
${ }^{7}$ Ver, também: WILLIS, 1979.

8 "Esto es sine dubio cosa bien ordenada,/ oír prímeramientre la liçión consegrada,/ monstrarla con sus lenguas que es fe acabada;/ desén comprir la obra, ofrecer la obrada. Quando corrié la leï en el tiempo primero,/ quando sacrificavan non ofricién dinero,/ mas o toro o aves o cobrón o carnero,/ pero fue encerrado todo en un Cordero./ Christo fue el cordero, fijo de tal Cordera,/ que nin depués nin ante non ovo compañera;/ éssi fue cerradura de la leï primera,/ e ordenó la nueva firme e verdadeira" (BERCEO, 1992).

${ }^{9}$ Como expôs Jean Guitton, os cristãos consideravam que a vinda de Cristo foi fundamental para a demarcação de tempo humano e histórico. Segundo ele, a dimensão histórica da vida, ausente na religião mitológica antiga, tornou-se fundamental para o cristianismo, pois retraçava os desígnios de Deus para os homens (GUITTON, 1959, p. 400-406).

10 “Todos los sacrificios, os de la ley primera/ todos significavan la Hostia verdadera;/ ésta fue Jesu Christo, que abrió la carrera/ por qui tornar podamos a la sied cabdalera" (BERCEO, 1992).

${ }^{11}$ Orígenes de Alexandria, um dos padres gregos do século III.

12 “Todas estas ofrendas, las aves e ganados,/ traen sinificança de oscuros mandados;/ todos en Jesú Christo hí fueron acabados,/ que ofreció sua carne por los nuestros pecados” (BERCEO, 1992).

${ }^{13}$ A respeito da leitura do Velho Testamento como anúncio do Novo pelos pensadores medievais, ver: SMALLEY, 1981.

14 “El cabrón que matava la gent sacerdotal,/ a Él sinificava, la su carne mortal;/ el que vivo fincava, que non prendié nul mal,/ la natura divina, la raíz spirital” (BERCEO, 1992).

15 "En el pan y el vino, hí finca el sabor,/ mas non es pan nin vino, cosa es muy mejor:/ cuerpo es de don Christo, el nuestro Salvador;/ qui esto non creyesse serié en grant error." (BERCEO, 1992).

16 “Del lat. eclesiástico transubstantiatĩo, -ōnis" (REAL ACADEMIA ESPAÑOLA, 2001, v. 2, p. 2213). A polêmica sobre a presença real do corpo de Cristo na Eucaristia emerge no contexto do IV Concílio de Latrão. Por volta do terceiro quartel do século XIII, as explanações sobre como seria possível que o corpo e sangue de Cristo se fizessem presente no altar tornaram-se mais complexas (MACY, 2012, p. 378).

${ }^{17}$ A respeito da participação dos bispos ibéricos nesse concílio, ver o clássico estudo de Peter Linehan (1975).

${ }^{18}$ Refere-se ao clérigo que canta a missa.

${ }^{19}$ Refere-se a um animal de rapina.

${ }^{20}$ O editor do documento, o célebre pesquisador Pedro Cátedra, aventa que a palavra "história" diz respeito ao documento utilizado pelo Gonzálo de Berceo para compor seus versos.

21 “Después el santo clérigo, el que la missa canta,/ dando grandes sospiros toma la hostia santa;/ quebrántala dos veces, luego que la levanta,/ fácela tres zaticos en lo que la quebranta. El pedazo que tiene en la derecha mano,/ con que signa el cáliz essi missacantano,/ éssi faz por los vivos, por el pueblo christiano,/ que libre Dios las almas del rabioso milano./ De los dos que li quedan, el uno faz memoria/ de las almas purgadas que son con Dios en Gloria;/ el tercero cantiello, como diz la istoria/ ruega por los que lazran en la ley porgatoria" (BERCEO, 1992).

22 Segundo Boquet e Nagy, a renovação gregoriana da eucaristia contribuiu para colocar o corpo de Cristo no centro da instituição eclesiástica e da vida devocional (NAGY; BOQUET, 2015, p. 260).

${ }^{23}$ Este religioso chegou a ser custódio de seu convento e influente na corte de Afonso X (RUCQUOI, 1996, p. 71).

24 “Han brotado las flores em nuestra tierra, ha llegado el tempo de la poda” (LILLO REDONET, 2011, p. 123).

${ }^{25}$ Na sequência do trecho já transcrito na nota anterior, Juan Gil acrescenta: “Y bajo la metáfora de las flores nos traen a la memoria el sacramento de la Pasión del Señor cuan se disse primero: Han brotado las flores... etc Cuanto más de acerca la Pasión de Cristo tanto mayor deve ser la devoción de sus fieles y la purificación de las almas." (LILLO REDONET, 2011, p.123).

${ }^{26}$ A respeito da menção aos vegetais nos escritos espirituais para referir a Cristo e à Paixão, Sara Ritchey afirma que estes elementos foram importantes para se tornar mais palpável e inteligível o pressuposto cristão da presença de Deus na terra (RITCHEY, 2008).

27 “En las flores podemos considerar tres cosas por las que podemos comparar la Pasión de Cristo com las flores. Se encuentran, pues, em las flores una rojez vivacísima, una blancura intensísima, un olor agradabilísimo. Y según lo dicho em el Hijo de Dios puede encontrarse la rojez de la Pasión, la blancura de su inocencia, el olor de todas sus virtudes y gracias" (LILLO REDONET, 2011, p. 123).

${ }^{28} \mathrm{~A}$ árvore refere-se à perdição da Queda e, após a vinda de Cristo, passa a simbolizar a reversão do pecado original, a redenção dos pecados. A identificação da árvore à cruz de Cristo derivou de formulações de pensadores como Ambrósio 
de Milão, que relacionou a madeira à cruz. Outros escritos teológicos, espirituais ou líricos, também associaram a madeira à carne de Cristo (RITCHEY, 2014, p. 38-39).

29 “En tercer lugar la cruz de Cristo es una flor a causa del olor de sus bienes, gracias y virtudes. Pues de ella no sale cualquier olor sino el olor de la viña, pues, como el olor de la viña ahuyenta a los sapos así el olor de la cruz de Cristo ahuyenta a los demonios. Por lo que el que es la vida verdadera y la viña verdadera pudo decir aquello del Eclesiástico 24: Yo fructifiqué como una viña la dulzura de mi olor y mis flores son fruto de honor y honestidade. Él mismo quiso deshonrarse para que tú honrases, quiso perder la honestidad para que tú la adquirieses" (LILLO REDONET, 2011, p. 124).

${ }^{30}$ A partir dos séculos XII e XIII, com o novo interesse pela encarnação e sofrimento, com a afirmação da devoção eucarística e a presença real de Cristo, o mundo material é aceito como meio para sondar ou contatar o divino (NAGY; BOQUET, 2015, p. 262, 268; RITCHEY, 2014, p. 16).

${ }^{31}$ Ver nota 25.

${ }^{32}$ Para panorama geral da maneira como a celebração da Eucaristia estruturava-se a partir do século XIII, ver: DE CEVINS; MATZ, 2010, p. 247-249.

33 “Dar la penitencia non conviene sinon á homes señalados á quien se deben los homes confesar; et esto se entiende primeramiente por todos los prestes que son ordenados de misa, por el noble oficio que tienen de sagrar el cuerpo de nuestro señor lesu Cristo, et son en lugar de los Apóstoles" (ALFONSO X, 1807, p. 135).

${ }^{34}$ Sobre a complexa relação entre o poder temporal e o religioso no que diz respeito especificamente à missa, ver: VOGEL, 1980.

${ }^{35}$ Sobre o papel do escrito para o ordenamento moral e social, ver: RAMÓN LODARES, 1993.

${ }^{36}$ Para uma visão ampla acerca da política de repovoamento, ver: VALDEÓN BARUQUE, 1996, p. 29-101. Sobre o mesmo tema, consultar: BERNAL ESTÉVEZ, 1998.

37 “Y como que el sacramento del Cuerpo y Sangre de Cristo es el que con más frecuencia se administra, deben con él ser más cautos los ministros, porque se puede errar en el con más peligro: conviene por lo tanto conocer su materia y forma" (TEJADA Y RAMIRO,1859, p. 514, grifo nosso). A versão original em latim dessas constituições também foram publicadas no décimo volume da coleção Synodicon Hispanum (GARCIA Y GARCIA, 2010).

38 "La materia del sacramento del cuerpo de Cristo es un pan de trigo puro e azimo, y vino de vid mezclado con una poca agua, conservando la naturaleza de vino" (TEJADA Y RAMIRO, 1859, p. 514).

39 Uma exceção era o sacramento da Penitência. Nesse rito, a matéria não era a água ou qualquer outro objeto, mas a contrição (Cf. LOPEZ GONZALEZ, 1991, p. 96).

${ }^{40} \mathrm{Na}$ Eucaristia, a experiência sacramental não se cristaliza apenas pelo comer, mas pela conjugação entre ver, provar ou tocar no momento da elevação da hóstia (BÉRIOU, 2018, p. 220-221; ASTELL, 2006, p. 1-6).

41 “La forma que ha de observarse en la consagración del Cuerpo de Cristo es la siguiente: Este es mi Cuerpo; después de cuyas palabras será elevado con devoción y humildad. La forma de la consagración de la Sangre es la que sigue: Este es pues el cáliz de mi Sangre, del nuevo y eterno Testamento, misterio de fe, que por vosotros y por muchos será derramado en remisión de los pecados: después de cuyas palabras elevará el cáliz con devoción y humildad" (TEJADA Y RAMIRO, 1859, p. 514)

${ }^{42} \mathrm{O}$ célebre pesquisador Walter Ullmann destaca que as assembleias eclesiásticas foram importantes para tornar muitas das pautas da Igreja “socialmente realizáveis” (ULLMANN, 1971, p. 1).

${ }^{43}$ No que diz respeito aos manuais de confessores escritos em castelhano, ver: SOTO RÁBANOS, 2006.

44 “Consagrar non debe ningunt clérigo el cuerpo de nuestro señor lesu Cristo quando dixiere la misa, á menos de haber estas tres cosas, pan, et vino et agua. Et este pan á que llaman hostia ha de ser de farina de trigo, amasada tan solamiente con agua sin levadura et sin otro mesclamiento ninguno, et débelo facer el clérigo muy limpiamiente: et non debe poner vino en el cáliz solo ó agua, mas amos á dos los debe hi mezclar; et esto es porque sallió del costado de nuestro señor lesu Cristo quando le dieron con la lanza sangre et agua; et debe poner mas del vino que del agua. Et este pan múdase verdaderamiente en el cuerpo de nuestro señor lesu Cristo, et el vino et el agua en su sangre por el poder de Dios et por las santas palabras que dice el clérigo, que dixo nuestro señor lesu Cristo el dia del Jueves de la cena quando tomó el pan et el vino en el dia sobredicho, et dixo á los apóstoles: este es mi cuerpo et mi sangre. Et quando estas palabras dice el clérigo debe alzar la hostia que la vea el pueblo, et estonce deben todos fincar los hinojos, et alzar las manos á Dios et decir asi: adórote señor lesu Cristo, et bendigo el tu santo nombre porque redemiste el mundo por tu cuerpo et por tu sangue. O puede decir esta oracion, ó otra de aquellas que suelen decir en aquella sazon" (ALFONSO X, 1807, p. 179-180). Dada a importância dessa lei, foi colocado o texto na íntegra em nota.

45 “Rézio” do espanhol recio, isto é, “flerte, robusto, vigoroso” (REAL ACADEMIA ESPAÑOLA, 2001, v. 2, p. 1913). 
${ }^{46}$ No original, está a palavra “onde” empregada no sentido de "por cual razón” (REAL ACADEMIA ESPAÑOLA, 2001, v. 2, p. 1622).

47 “E commoquier que los baptizados sean guarneçidos del sacramento de la confirmaçion, pero porque tantas son las tenptaçiones del diabo contra el, commo que cada dia cae, malos de pecados, por ende, para estar mas fuerte e mas rezio en la graçia de Dios, menester fue aver comer spiritual, que es corpus Christi e la sangre verdadera e muy preçiada del, onde dize el 'yo so pan verdadero que del çielo desçendi, si alguno comiere deste pan bivira para siempre', e diz el 'la mi carne verdaderamente es comer, e la mi sangre verdaderamente es bever', e por este comer son criadas e nudridas las almas de los justos" (GARCÍA Y GARCÍA, 1993, p. 302).

${ }^{48}$ Sobre a ação pastoral desse prelado, consultar: LUIS MARTIN; LINAGE CONDE, 1987.

${ }^{49}$ Para uma visão geral da produção catequética da Espanha, ver: LLORENTE RESINES, 1997.

50 "E ay otra cosa por que es establesçido este sacramento, que asi commo por comer del fruto vedado fue perdido el ome, asi por comer del fruto de vida sea reparado" (GARCÍA Y GARCíA, 1993, p. 302).

51 “E deve saber el clerigo que en el Sacramento del altar son tres cosas. La primera cosa es aquella que paresçe forma de pan e de vino. La segunda es el Cuerpo de Jesuchristo. La terçera, la virtud del Sacramento, que es unidat e caridat que es entre Jesuchristo e los catolicos. [...] La primera cosa sinifica las dos postrimeras: el Cuerpo e la Sangre e la unidat; e la segunda, que es Corpus Christi, sinifica la unidat dicha que es entre los catolicos e Jesuchristo" (GARCíA Y GARCÍA, 1993, p. 304-305).

52 “La palomba significa la su simplicidad;/ la tórtora es signo de su castidad;/ los panes figuravam que Él era verdad, carrera, paz e vida en pan de caridade" (BERCEO, 1992).

Data de recebimento: 30/10/2018

Data de aprovação: 20/02/2019 